\title{
Moje pierwsze spotkania z bł. Edmundem Bojanowskim
}

\begin{abstract}
\ubiegłym roku Siostry Służebniczki z Dębicy poprosiły mnie o recenzję $\checkmark$ potężnego dzieła zawierającego „Inedita” błogosławionego Edmunda Bojanowskiego. Lektura tego obszernego i niełatwego w odbiorze dzieła stała się okazją do ponownego spotkania się z tym niezwykłym, wiernym uczniem Chrystusa, dziś błogosławionym. Te pierwsze spotkania były „niezaplanowane”, ale na pewno mieściły się w planach Bożej Opatrzności, które w miarę upływu lat, coraz wyraźniej odkrywam. Dlatego chcę powiedzieć nieco o moich, i nie tylko moich, pierwszych spotkaniach z naszym Błogosławionym.
\end{abstract}

\section{Uwarunkowania historyczno-kościelne}

Aby je poznać, trzeba się nam przenieść do lat pięćdziesiątych ubiegłego stulecia, dokładnie do lat 1951-1955. Były to dla Polski i naszego Kościoła trudne czasy stalinowskie. Mimo, iż sam tyran zmarł 5 marca 1953 r., władze PRL-u kontynuowały ateizację społeczeństwa, zwłaszcza starały się o laicyzację szkół. Tak o tym pisał w 1947 r. ówczesny rektor poznańskiego seminarium ks. Aleksy Wietrzykowski: „Istnieje obawa, że w zmienionym porządku politycznym, jaki zapanował w kraju, zabraknie wkrótce powołań do naszego seminarium, a to wskutek potęgującej się, z dnia na dzień, propagandy antyreligijnej w szkołach państwowych. Ponadto obawiamy się, że młodzież wychowana i kształcona w tych szkołach, w duchu bezbożnego materializmu, nawet gdyby dość licznie pukała do furty seminaryjnej, nie przyniesie ze sobą odpowied-

\footnotetext{
* Ks. PROF. DR HAB. Anzelm WeIss - historyk, emerytowany profesor zwyczajny nauk teologicznych, Instytut Historii Kościoła, Wydziału Teologii Katolicki Uniwersytet Lubelski Jana Pawła II. E-mail: anweiss@op.pl.
} 
niej postawy duchowej, ani pod względem umysłowym, ani pod względem moralnym".

Trzeba też wspomnieć, że wśród szykan stosowanych wobec młodzieży była zasada reglamentacji w przyjmowaniu do szkół ogólnokształcących i na wyższe studia. Przy rekrutacji najważniejszym kryterium było pochodzenie społeczne rodziców oraz ich przynależność partyjna. W pierwszej kolejności przyjmowano dzieci partyjnych, robotników i chłopów. Niewielkie szanse miało potomstwo przedwojennych urzędników, profesorów, wojskowych, bogatszych rolników zwanych obszarnikami, właścicieli sklepów czy małych firm, tzw. „prywaciarzy”. A właśnie najliczniejsze powołania kapłańskie wywodziły się wówczas z tej społecznej, patriotycznej klasy średniej, niechętnej nowej władzy.

W kręgach kościelnych obawiano się, że sytuacja powyższa może wpłynąć na zmniejszenie się liczby kandydatów do kapłaństwa. By temu zaradzić w wielu diecezjach i zakonach wrócono do przedwojennej tradycji zakładania niższych seminariów duchownych (NSD). Warto wspomnieć, że zasadniczo niższe seminaria powoływano z myślą o formowaniu kandydatów do kapłaństwa, ale mogli się tam również uczyć i zdobywać ogólne wykształcenie chłopcy nie mający takich planów.

\section{Niższe Seminarium Duchowne Archidiecezji Poznańskiej Ostrów Wielkopolski - Wolsztyn - filia wolsztyńskiego seminarium w Gostyniu}

W naszej poznańskiej diecezji, która w czasie wojny poniosła ogromne straty personalne w szeregach kapłańskich ( 240 zostało zamordowanych, a ponad 200 dalszych przeszło przez więzienia lub obozy koncentracyjne) dawał się we znaki nie tylko brak kapłanów, ale i lęk o brak nowych powołań. By temu zaradzić powołano w naszej diecezji pełnomocnika do spraw troski o powołania kapłańskie. Został nim wspomniany już ks. Aleksy Wietrzykowski. Wykształcony we Francji i znający dobrze realia tamtejszego Kościoła był gorliwym zwolennikiem utworzenia niższego seminarium. Jak się wydaje - pozostający pod wpływem jego sugestii - ks. abp Walenty Dymek, wydał 25 sierpnia 1949 r. dekret o utworzeniu niższego seminarium. Zostało ono ulokowane w dawnym konwikcie biskupim w Ostrowie Wielkopolskim i dnia 1 IX 1949 r. rozpoczęło działalność.

Inicjatywa trafiła na podatny grunt i odpowiadała społecznym potrzebom. Zgłosiło się bardzo dużo chętnych, ale z racji szczupłości miejsca, przyjęto tylko 55 kandydatów. Po roku, ze względu na konieczność tworzenia następnych, nowych klas, poszukiwano innego, obszerniejszego lokum. Znaleziono je w Wolsztynie, w budynku dawnego sierocińca Sióstr św. Wincentego a Paulo (seminarium działało tu do 1960 r.). Wkrótce i ten gmach okazał się za mały, 
ponieważ z roku na rok, wzrastała liczba kandydatów. Dlatego w 1951 r. utworzono filię wolsztyńskiego niższego seminarium w Gostyniu w pomieszczeniach klasztornych ojców Filipinów na Świętej Górze. Tu mieli się uczyć chłopcy z klasy 1 i 2, a z 3 i 4 w Wolsztynie. Filia gostyńska działała tylko do czerwca 1954 roku.

Pod względem duchowym, klimatycznym i „oddalenia od świata” miejsce było jak najtrafniej dobrane. Były tu też doskonałe warunki dla rekreacji. Za klasztornymi zabudowaniami rozciągał się wielohektarowy sad, aż do lasu. Jego obejście, po śniadaniu, a przed lekcjami, należało do żelaznych punktów porządku dziennego. Do dyspozycji niższego seminarium Księża Filipini przekazali część budynku klasztornego, a mianowicie cały parter z wyjątkiem refektarza kongregacyjnego (tj. zakonnego) i dwóch pokoi. Na piętrze 6 lokali od strony wschodniej, pomieszczenia uczelniane oraz sanitariaty od strony północnej. Udostępniono też sprzęt ruchomy w postaci łóżek, w tym część piętrowych, szaf, stołków, krzeseł, ławek. Rzeczywiście pod względem lokalowym seminarium miało świetne warunki. Dlatego na pierwszy kurs przyjęto w roku szkolnym 1951/1952 aż 92 chłopców.

Tę gromadę chłopców podzielono na dwie klasy: Pierwszą A, która pod koniec roku miała 39 oraz Pierwszą B, z liczbą 36 chłopców. Z tych dwu klas, w roku następnym zostało 33 uczniów, pozostali przeszli do Wolsztyna. W roku szkolnym 1952/1953 przyjęto do Gostynia 91 kandydatów. Z tej liczby na roku drugim pozostało w Gostyniu 28, a reszta w Wolsztynie. Na najbardziej interesującym mnie roczniku 1953/1954, przyjęto 81 chłopców. W tej liczbie aż 4 przyszło ze Szkoły Podstawowej Nr 2 z Wolsztyna, z czego ogromnie się cieszył nasz katecheta - wikariusz wolsztyński ks. Marian Przykucki, późniejszy poznański biskup pomocniczy, następnie ordynariusz chełmiński, a w końcu arcybiskup szczecińsko-kołobrzeski. Niestety, tylko jeden z tej czwórki został kapłanem. Trzeba zaznaczyć, że z seminarium gostyńskiego, corocznie odchodziło wielu chłopców, którzy albo nie dawali sobie rady z nauką, albo rozpoznawali, że nie jest to ich miejsce w życiu. Niemniej każdego roku uczyło się tutaj około 100 seminarzystów, którym diecezja dawała wykształcenie i utrzymanie.

Życie seminaryjne toczyło się zgodnie z przepisami i ustaleniami zawartymi w „Regulaminie dla wychowanków NSD Archidiecezji Poznańskiej”, który organizował życie seminaryjne w sposób ramowy i ogólny. Precyzował je dokument, zwany „Dziennym rozkładem zajęć”. Życie seminaryjne nie wyczerpywało się tylko w lekcjach, nabożeństwach, nauce własnej, modlitwach. Stwarzało różne formy działalności i pozwalało na rozwijanie swoich zainteresowań, np. sportowych, turystycznych, muzycznych, filmowych, spacerowych. Jak już wspomniałem, jeden spacer był obowiązkowy. To ten po śniadaniu, a przed lekcjami dookoła Świętej Góry. Wielu wychowanków, i ja też, tego „spaceru” nie wspomina zbyt przyjemnie, gdyż 1) był nakazany, 2) zbyt długi i pokonywany, jak to bywa u chłopaków, na wyścigi, w forsownym tempie, 3) powodował 
duże zmęczenie i „spanie” na pierwszych lekcjach. Warto jeszcze wspomnieć, że alumnów, w razie potrzeby, angażowano do pomocy w gospodarstwie i do wykonywania prac porządkowych. Wstępem do nich było, na początku roku, samodzielne wypchanie słomą siennika, na którym się spało. I przez tę aktywność sprawdzało się przysłowie: „Jak sobie pościelisz, tak się wyśpisz”. Pomagaliśmy też przy zwożeniu ziemiopłodów, kopcowaniu, przebieraniu kartofli. Jesienną porą zbieraliśmy tzw. „kociupki” - czyli dzikie owoce na wyśmienitą marmoladę. Jej smażenie odbywało się również pod naszym nadzorem.

Wiek przyjętych uczniów, zwanych alumnami, wahał się od 13 i 14 roku życia, wyjątkowo do 16. Uczelnia realizowała w zasadzie program nauczania obowiązujący w państwowych liceach ogólnokształcących, z poszerzonym programem nauki religii, łaciny, śpiewu, gdyż spodziewano się, że wielu z nich wybierze w przyszłości drogę życia kapłańskiego.

Kadrę pedagogiczną tworzyli wychowawcy, którymi byli księża diecezjalni, pełniący również funkcje nauczycielskie oraz nauczyciele świeccy. Ci ostatni rekrutowali się najczęściej z emerytowanych profesorów gimnazjalnych lub „niereformowalnych" i zwolnionych z racji politycznych przedwojennych pracowników naukowych. Nie wszyscy z nich mieli odpowiednie przygotowanie pedagogiczno-zawodowe, lecz wszystkich cechowała głęboka religijność, przedwojenny patriotyzm i poczucie odpowiedzialności za powierzoną im młodzież.

Oprócz wspomnianych, naturalnych walorów, gostyńska wspólnota niższego seminarium znalazła się w obrębie oddziaływania duchowości i atmosfery sanktuarium Świętej Góry, z cudownym obrazem Matki Bożej - Róży Duchownej. I jak się wydaje, to Boża Opatrzność wybrała Świętą Górę, z wielowiekowym klasztorem i maryjnym sanktuarium na miejsce, w którym miały się zaczynać początki wykształcenia humanistycznego i duchowej formacji wielu kapłanów naszej diecezji.

Wiek wcześniej, w cieniu świętogórskiego kościoła i klasztoru, dojrzewała duchowa osobowość Edmunda Bojanowskiego. Świątynia ta już od najmłodszych lat była Edmundowi Bojanowskiemu szczególnie bliska. W syntetycznym zapisie ujmuje to autorka Przewodnika śladami bł. E. Bojanowskiego. „To miejsce związane jest z jego cudownym uzdrowieniem. Mieszkając w Grabonogu, niemal codziennie przemierzał ok. $3 \mathrm{~km}$, aby uczestniczyć we Mszy św., w różnych uroczystościach oraz korzystać z sakramentów. Świątynia ta była dla Edmunda również miejscem wielogodzinnego, cichego trwania przed Najświętszym Sakramentem. Spieszył do niej, przeżywając radości i smutki. Można powiedzieć, że wszystko tu jest niemym świadkiem jego duchowego wzrastania i rozwoju dzieła" ${ }^{1}$.

${ }^{1}$ s. M. Laureta Turek (red.), Przewodnik śladami bł. Edmunda Bojanowskiego, Wrocław 2011, s. 21. 
W latach 1951-54 pamięć o obecności na Św. Górze Edmunda Bojanowskiego była bardzo żywa. Przypominali o niej Ojcowie Filipini, a także nasi wychowawcy, stawiając Edmunda jako wzór chrześcijanina, dążącego do świętości poprzez pracę dla dobra najbardziej potrzebujących, do których zaliczano wówczas dzieci, zwłaszcza wiejskie. Również ważne dla naszej formacji były piesze „pielgrzymki” do miejsc związanych z działalnością Bojanowskiego, w ramach wycieczek rekreacyjnych.

Ponieważ w latach, o których mówimy, literatura na temat Edmunda Bojanowskiego była bardzo uboga, a jego twórczość prawie nieznana, to forma ustnego przekazu przez starszych kapłanów i „turystyka pielgrzymkowa” były niemal jedynymi źródłami informacji o Bojanowskim i miejscami pierwszego z Nim spotkania. Przekazywane w żywej formie oraz fizyczna obecność w miejscach życia i jego działalności sprawiały, że w sercach wielu młodych alumnów zapalało się światełko sympatii do naszego Błogosławionego.

Osoba Edmunda Bojanowskiego i poznawanie dzieł, które podejmował, budziła u nas młodych podziw, ale też rodziła niepokojące pytanie: dlaczego tak świątobliwy człowiek nie został kapłanem? Zapytaliśmy o to, prosząc o wyjaśnienie dyrektora naszego gostyńskiego seminarium ks. Henryka Kamińskiego. A on, na jednej z konferencji wyjaśnił nam, że jeśli Pan Jezus chce, aby mężczyzna został kapłanem, obdarza go odpowiednimi predyspozycjami. Są nimi: „sanctitas, scientia, sanitas” („świętość - pobożność, zdolności - wiedza, zdrowie”). Jeżeli jednej z nich brakuje to znak, że nie został wybrany i powinien inną drogą zmierzać do zbawienia. Dzięki temu wyjaśnieniu lepiej zrozumieliśmy fenomen niezwykłej drogi życiowej Edmunda Bojanowskiego i z coraz większym podziwem oraz życzliwością patrzyliśmy na założone przez niego Wspólnoty.

\section{Siostry Służebniczki a Seminarium}

Tym bardziej, że na co dzień doświadczaliśmy życzliwej, serdecznej troski i pomocy ze strony Sióstr Służebniczek Niepokalanego Poczęcia Najświętszej Maryi Panny, które pracowały na rzecz klasztoru i seminarium. Na podstawie zachowanych dokumentów wizytacji kościelnych udało się ustalić, że na Świętej Górze w roku szkolnym 1951-1952: „Z wielkim poświęceniem pracują Siostry Służebniczki Maryi z Dębicy. Jest ich pięć. Dwie są zaangażowane dla nas (tzn. dla seminarium). Poza tym dwie osoby świeckie. Pracują z zapałem i poświęceniem. Jesteśmy z nich zadowoleni"2.

Z podobnego dokumentu spisanego w 1953 r. dowiadujemy się, że: „Kuchnię i magazyn prowadzą dwie siostry ze Zgromadzenia Sióstr Służebniczek Maryi,

\footnotetext{
${ }^{2}$ Archiwum Archidiecezjalne w Poznaniu (AAP), sygn. OA XIII 457, k. 33.
} 
mając do pomocy sześć dziewcząt. Od początku stycznia 1953 r. przybyła jeszcze jedna siostra dla spraw biurowych oraz infirmerii”’. Z jej obecnością wiąże się pewien osobisty, ważny dla mnie wątek. Piękne pomieszczenia klasztorne, były jednak bardzo zimne. I gdy w 1953 r. przyszły wczesne, jesienne chłody poważnie się rozchorowałem. Ponieważ trudno było ustalić przyczynę choroby, postanowiono wysłać mnie do powiatowego szpitala w Gostyniu. Ja ze wszystkich sił broniłem się przed taką ewentualnością. Żywiłem bowiem takie przekonanie, że do szpitala idzie się po to, żeby umrzeć. Tak sześć lat wcześniej stało się z moją mamą. A ja nie miałem ochoty jeszcze umierać. Wtedy ks. Dyrektor poprosił siostrę z infirmerii, żeby mnie uspokoiła i przekonała, że szpital jest miejscem, gdzie nie wszyscy ludzie umierają, ale gdzie większość odzyskuje zdrowie. Obiecała też odwiedzić mnie w szpitalu. Po paru dniach obserwacji lekarze zdiagnozowali, że powodem mojej choroby są ropne migdały, które należy usunąć. Zabieg wykonano. Do dziś towarzyszy mi wspomnienie przeżytego wówczas bólu. Zabieg wykonano prawdopodobnie bez podawania środków znieczulających. Ponieważ nie miałem jeszcze ukończonych 14 lat, umieszczono mnie na oddziale dziecięcym. Tu nie było odwiedzin. Siostra, tylko sobie znanym sposobem, uzyskała pozwolenie na odwiedzanie mnie i tak, zgodnie z charyzmatem Zgromadzenia, dobrym słowem i obecnością, podtrzymywała na duchu chorego trzynastolatka, zagubionego w obcym środowisku ${ }^{4}$. Niestety, nie pamiętam imienia tej siostry, ale jestem jej dozgonnie wdzięczny.

\section{Kapłani - Wychowawcy}

W formowaniu powołania kapłańskiego ważną rolę odgrywa osobowość i przykład innego kapłana. Tak było też w Gostyniu. Wśród naszych wychowawców postacią wyjątkową i wręcz charyzmatyczną był wspomniany już dyrektor ks. Henryk Kamiński. Urodził się w 1920 r. w Ostrowie Wielkopolskim. W 1945 r. wstąpił do Seminarium Duchownego w Gnieźnie. Święcenia kapłańskie otrzymał 12 VI 1949 r. w Poznaniu. Po krótkim wikariacie w Nowym Mieście od 15 VIII 1949 r. do czerwca 1954 r. pracował w Archidiecezjalnym Niższym Seminarium Duchownym, początkowo jako ojciec duchowny, a później dyrektor Oddziału

3 AAP sygn. SD nr 439 Akta Niższego Seminarium Duchownego w Wolsztynie i Gostyniu, k. 85.

${ }^{4}$ Na zdjęciu zrobionym w roku szkolnym 1953/54 przedstawiającym społeczność Niższego Seminarium w Gostyniu są alumni, księża, nauczyciele oraz 3 siostry Służebniczki. Siostra dr Agnieszka Skrzypek podjęła się trudu ustalenia nazwisk tych sióstr. W oparciu o „Kronikę domu na Świętej Górze” oraz Akta osobowe z Archiwum Głównego Sióstr Służebniczek w Dębicy - Siostra Doktor - przypuszcza, że uwiecznione na fotografii siostry to: s. Metodia Bachorz, s. Wenanta Żołądż i s. Fidelisa Noga. Siostrze Agnieszce za trud poszukiwań i cenne informacje serdecznie dziękuje. Bóg zapłać. 
Gostyńskiego. W 1950 r. na Uniwersytecie Jagiellońskim uzyskał magisterium, przedstawiając pracę pt. Wychowanie młodzieży w małych seminariach w świetle encykliki Menti nostrae. Po likwidacji gostyńskiego oddziału Niższego Seminarium. W 1954 r. wstąpił do zgromadzenia pod nazwą Towarzystwo Chrystusowe dla Polonii Zagranicznej. W szeregach Chrystusowców pełnił szereg odpowiedzialnych funkcji, jako ojciec duchowny, proboszcz, misjonarz w Brazylii i Argentynie, a po powrocie do kraju również nie ustawał w gorliwości apostolskiej. Zmarł w wigilię święta Narodzenia Najświętszej Maryi Panny 7 września 1998 r.

Kiedy poznaliśmy go w Gostyniu, pociągała nas w nim jego heroiczna wiara. Wskazywał nam, że całkowitego i bezgranicznego zawierzenia Bogu powinniśmy się uczyć od Matki Najświętszej, na modlitwie. To Niepokalana nauczyła go, by w najtrudniejszych sytuacjach życiowych: „Wierzyć nadziei wbrew nadziei”. A doświadczył Jej cudownej opieki w 1940 r. Został wówczas zaaresztowany przez Gestapo w Warszawie i osadzony w więzieniu przy ul. Daniłowiczowskiej. Wraz z kolegą przygotowali ucieczkę. Na termin „opuszczenia” więzienia wybrali dzień 11 lutego - święto Matki Boskiej z Lourdes. Akcja zakończyła się szczęśliwie, po linie spuszczonej z pierwszego piętra okna w kaplicy więziennej, wydostali się na wolność. Ks. Henryk uważał, że za ten cud uratowania życia musi z wszystkich sił pracować dla Jej chwały. Uczył nas szacunku do tajemnicy krzyża. Mawiał: „Zbawienie przyszło przez krzyż”. Dlatego m.in. wszystkim alumnom ofiarował niewielkich rozmiarów drewniany krzyżyk, z wypisanym na odwrocie imieniem alumna oraz słowami: „W tym znaku zwyciężysz”. Niektórzy z nas. przez całe życie nosili ten krzyż zawieszony na szyi, a nawet prosili, by go włożyć do trumny (np. Tadeusz Przybyła).

Kierując się gorliwością duszpasterską i miłością do cierpiącego Zbawiciela, wyreżyserował wraz z ks. prefektem Edwardem Pospiesznym przepiękne Misterium Pasyjne Męki Pańskiej. Spektakle tego Misterium Pasyjnego, grane przez alumnów, odbywały się we wszystkie soboty i niedziele Wielkiego Postu 1954 roku, a sława pięknych i głęboko religijnych przeżyć, które rodziły się w sercach oglądających, ściągała tłumy wiernych z najbliższej i dalszej okolicy.

Drugim kapłanem, który zaważył na naszej formacji był ks. Edward Pospieszny. Urodził się w 1922 r. w Komornikach. 22 lutego 1950 r. otrzymał święcenia kapłańskie. Od 1 IX 1951 r. do 1954 r. pracował w Niższym Seminarium Gostyniu, jako prefekt i nauczyciel przedmiotów matematyczno-przyrodniczych. Niezwykle aktywny, świetny organizator wycieczek, wypraw. Wspaniale potrafił zachęcać do poznawania otaczającego nas świata przyrody, np. zbierania ziół, robienia zielników itp. Uczył m.in. astronomii, pokazywał piękno stworzonego przez Boga firmamentu niebieskiego. Zobowiązał nas do kupna planszowego atlasu nieba i nauczył posługiwania się nim. Zachęcał nas do obserwacji i kontemplacji kosmosu nad nami i wokół nas. Niejednego z alumnów „Zaraził” astronomiczną pasją, np. Zenona Grocholewskiego. 


\section{Wychowankowie}

Zwykle gdy chcemy ocenić wartość lub prestiżowe znaczenie danej szkoły pytamy o losy wychowanków czy też osiągnięcia absolwentów. W przypadku Niższego Seminarium w Gostyniu trudno mówić o absolwentach, gdyż ono będąc filią wolsztyńskiego, pełniło funkcję pomocniczą. Chłopcy stawali się absolwentami dopiero po zdaniu matury w Wolsztynie. Możemy natomiast mówić o wychowankach, którzy rok lub dwa uczyli się w Gostyniu. Spośród przyjętych na pierwszy rok, znakomity procent kontynuował naukę w Wolsztynie, aż do zdobycia matury. Matura zdawana w Niższym Seminarium w latach 1953-1956 nie miała charakteru egzaminu państwowego. $Z$ tą maturą można było zostać przyjętym do Wyższego Seminarium Duchownego w Poznaniu, ale nie można było się ubiegać o przyjęcia na uczelnie państwowe. Dlatego absolwenci wybierający świecką drogę życia uzupełniali ten brak w liceach wieczorowych. Również absolwentów z lat 1953-56 będących już klerykami w seminarium zobowiązano do uzyskania państwowej matury. Wszyscy, a niektórzy z wyróżnieniem, zdali te maturalne, państwowe egzaminy, co dobrze świadczyło o poziomie wiedzy zdobywanej w niższym seminarium.

Szereg absolwentów świeckich (dziś już przeważnie na emeryturze), zajmowało społecznie ważne stanowiska w życiu naukowym, administracyjnym czy państwowym, np. prof. Sylwester Dworacki - prorektor Uniwersytetu Adama Mickiewicza w Poznaniu, mgr Eligiusz Szczepaniak - muzyk, mgr Bogdan Michalak - pedagog, Tadeusz Przybyła - malarz i in.

Ze stosunkowo dużej liczby gostyńskich uczniów, tylko ok. 30 zostało kapłanami diecezjalnymi, a 3 zakonnymi. $Z$ tego grona kapłańskiego, po specjalistycznych studiach w kraju lub za granicą (Rzym) Stolica Apostolska wyniosła czterech z nich do godności biskupiej. Wymienię tylko ich imiona i nazwiska, a opuszczę ich obszerniejsze życiorysy, zwłaszcza, że nie dotyczą one okresu gostyńskiego i są powszechnie znane. Biskupami zostali: ks. arcybiskup dr Juliusz Paetz, były metropolita Poznański, obecnie arcybiskup senior, ks. prof. Stanisław Napierała - organizator struktur diecezjalnych i pierwszy biskup diecezji kaliskiej. Biskup Józef Zawitkowski, który już w Gostyniu wyróżniał się wśród kolegów. Uzdolniony muzycznie, grał na różnych instrumentach, w tym na trąbce, dlatego zlecono mu w seminarium funkcję trębacza. Budził nas, grając o „nieludzkiej” godzinie: (5:30 lub 6:00) „Kiedy ranne wstają zorze” lub w dni maryjne: „Już od rana rozśpiewana”. Niewielu z nas miało wówczas zegarki. Ale był jeden kolega, rodem z Poznania, który na swoim zegarku, kontrolował naszego trębacza i robił mu „awanturę”, gdy chociaż trochę wcześniej nas zbudził. Zawitkowski ukończył niższe i wyższe seminarium w Warszawie. Został kapłanem archidiecezji warszawskiej, z której pochodził. Już po święceniach pogłębiał swoją wiedzę z zakresu muzykologii w Instytucie Musica Sacra w Aninie oraz 
w Sekcji Muzyki Kościelnej na Wydziale Teologicznym Akademii Teologii Katolickiej w Warszawie, gdzie ukończył studia muzyczne. Jest kompozytorem małych form muzycznych dla chórów i zespołów muzycznych, a także autorem tekstów znanych i chętnie śpiewanych pieśni kościelnych, m.in. Panie dobry jak chleb oraz Abyśmy byli jedno. Publikował pod pseudonimem Tymoteusz. W 1990 r. został biskupem pomocniczym archidiecezji warszawskiej. Słynie ze wspaniałych kazań, pełnych Słowa Bożego, poezji i historycznych odniesień.

Biskupem, który wyrósł z gostyńskiej gleby Niższego Seminarium i ducha Świętej Góry oraz charyzmatu Bojanowskiego, jest bez wątpienia Zenon kardynał Grocholewski - przyjaciel i opiekun wszystkich gałęzi Sióstr Służebniczek. Odegrał szczególnie ważną rolę w propagowaniu kultu, a potem w staraniach o wyniesienie na ołtarze błogosławionego Edmunda Bojanowskiego.

Pragnę jeszcze wspomnieć, że wielu moich kolegów - proboszczów, którzy „przeszli” przez Gostyń, w swojej późniejszej działalności kapłańsko-duszpasterskiej, było gorliwymi propagatorami kultu i pamięci o bł. Edmundzie, np. ks. Kazimierz Pachciarz, Zbigniew Kalina, Marian Dopieralski, i in. Kultem bł. Edmunda zajmowali się również moi wybitni koledzy: ks. prof. Romuald Niparko, a także śp. ks. prof. Antoni Lewek ${ }^{5}$.

Jestem serdecznie wdzięczny Lubelskim, czyli Dębickim Siostrom Służebniczkom za zaproszenie i zabranie mnie na Ogólnokrajową Konferencję Naukową, która miała miejsce 1 kwietnia 2017 r. w Gostyniu. Konferencja została poprzedzona złożeniem Najświętszej Ofiary Eucharystycznej w sanktuarium na Świętej Górze przed cudownym obrazem Matki Bożej Róży Duchownej, Królowej Wielkopolski. Liturgii przewodniczył Wielkopolanin, od młodości związany z tym miejscem, Zenon kardynał Grocholewski. W pięknym kazaniu głosił pochwałę prawdziwej miłości chrześcijańskiej, której istotą, obok pomocy w potrzebach materialnych, jest gorliwa troska o zbawienie bliźnich. Refleksje zobrazował w oparciu o fascynujący przykład błogosławionego Edmunda.

Dla mnie wyprawa, po prawie 60 latach, do Gostynia - Świętej Góry byłą niezwykle głębokim przeżyciem wspomnieniowo-religijnym. Powrotem do miejsca, „gdzie wszystko się zaczęło” na mojej kapłańskiej drodze.

Lublin, w uroczystość Podwyższenia Krzyża Świętego 2017

\footnotetext{
${ }^{5}$ Przy „odświeżaniu” pamięci korzystałem z książki: A. Weiss, R. Banaszak, Niższe Seminarium Duchowne Archidiecezji Poznańskiej (1949-1960), Poznań 1999.
} 